\title{
The seaweed (green macroalgae), Ulva sp. as bioindicator of metal pollution in the Mediterranean Coast, Alexandria region, Egypt
}

\author{
Samir M. Saeed and Yasser T. A. Moustafa* \\ Central Lab. for Aquaculture Research, Agricultural Research Center. \\ Limnology dept. \\ E-mail: ymoustafaonline@yahoo.com
}

\begin{abstract}
Changes in heavy metals $(\mathrm{Fe}, \mathrm{Mn}, \mathrm{Zn}, \mathrm{Cu}, \mathrm{Cd}$ and $\mathrm{Pb}$ ) concentrations in marine seaweed (green alga) Ulva sp. and seawater collected from the the Mediterranean Coast, Alexandria region, Egypt were investigated during monthly samplings from January to December 2012 to assess the spatial and seasonal variation of these elements as well as the pollutional status at this area. Fe had the highest concentration and $\mathrm{Cd}$ found the lowest one. There were statistically positive significant correlations among the levels of some metals in the macroalgae. The mean metals concentration in the Ulva tissue decreased in the order: $\mathrm{Fe}>\mathrm{Mn}>\mathrm{Zn}>\mathrm{Cu}>\mathrm{Pb}>\mathrm{Cd}$. Only, concentrations, $\mathrm{Fe}, \mathrm{Zn}$ and $\mathrm{Pb}$, in water showed significant $(\mathrm{P}<0.05)$ seasonal changes. $\mathrm{Fe}, \mathrm{Mn}, \mathrm{Zn}$ and $\mathrm{Cu}$ showed the greater spatial and temporal differences $(\mathrm{P}<0.05)$ in macroalgae tissues. The results showed that the studied area not faced heavy metals pollution. It is also concluded that Ulva sp. play an important role as a bioindicator for heavy metals contamination in seawater.
\end{abstract}

Keywords: Seaweed, Ulva sp., heavy metals, Mediterranean Coast

\section{INTRODUCTION}

Macroalgae are major primary producers in the marine environment and play an important role in food chains. They also used as a natural source of food and medicines especially in Asian countries. The seaweeds (macroalgae) are widely distributed in the ocean and seas, ranging from tide level to considerable depths or attached to substrates such as sand, mud, rocks, shells, and coral (Apaydn et al., 2010). Green macroalgae Ulva sp. is a widespread macroalgae occurring at all levels of the intertidal zone and grows along rocky or sandy coasts of oceans and seas (Apaydn et al., 2010). It was the most abundant seaweed at the Egyptian marine environment throughout the year (Abdallah, 2010).

The bioaccumulation and biomagnifications of heavy metals along trophic chains increase their toxicity in the aquatic environment over time (Kamala-Kannan et al. 2007). Marine macroalgae accumulate such elements, which are further transferred along the trophic chain by herbivores and detritivores. So, they are important bioindicator of the marine environmental pollution by these elements (Villares et al., 2001).

Ulva spp. have high accumulation capacity for metals, so they are used as bioindicators of metal pollution in different parts of the world (Villares et al., 2001; Lozano et al., 2003; Topcuoglu et al., 2010; Kamala-Kannan et al., 2007; Chaudhuri et al., 2007; Apaydn et al., 2010; Okuku and Peter, 2012; Rybak et al., 2013) and in the Mediterranean coast of Egypt (El-Moselhy et al., 2004; Abdallah, 2010; Abdallah and Abdallah, 2008). 
Many factors may influence the bioavailability of metals in algae including $\mathrm{pH}$, salinity, temperature, light, nutrient concentrations, oxygen, particulate matters and organic matters (Jothinayagi and Anbazhagan, 2009) and on the structural differences among the algae (Favero et al., 1996). It is also worth noting that physiological changes and growth can affect concentrations of metals in the macroalgal tissue (Villares et al., 2002).

The physical characteristics and locations of many coastal areas in Alexandria, Egypt make them vulnerable to contaminants. So, this study was conducted to assess the health of this aquatic ecosystem and contribute to the overall picture of metal inputs into this marine environment. Also, the seasonal variability of heavy metals concentration in water and macroalgal tissues of Ulva sp. was studied.

\section{MATERIALS AND METHODS}

\section{Sampling}

Water and seaweeds (green macroalgae, Ulva sp.) samples were collected monthly from January to December 2012 from two sites namely; Ras Al-Tin (A) and Al-Mountazah (B) along the north coast of Egypt, Alexandria region (Fig. 1).

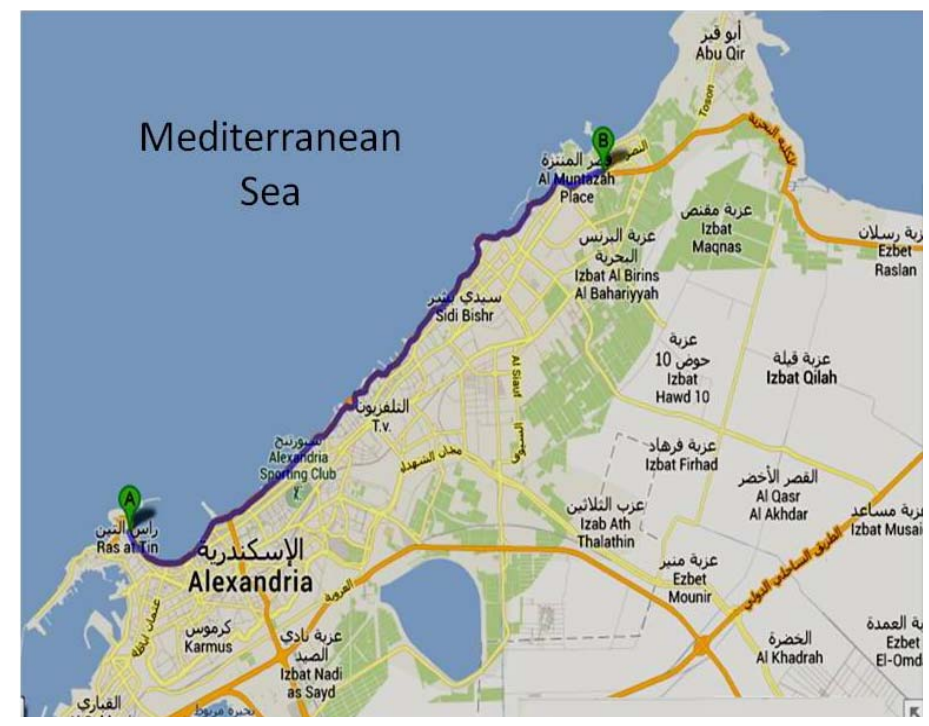

Fig. 1: Map illustrate the study sites (A and B)

\section{Laboratory analysis}

The sampled seaweeds and seawater were subsequently analyzed for iron $(\mathrm{Fe})$, manganese $(\mathrm{Mn})$, zinc $(\mathrm{Zn})$, copper $(\mathrm{Cu})$, cadmium $(\mathrm{Cd})$ and lead $(\mathrm{Pb})$ as follow:

\section{a) Seaweed}

All samples were dried, ground and homogenized in the laboratory prior to analysis. Samples were attentively washed in tap water to remove salt water, sand, and particulate matter, next rinsed in distilled water to remove any mineral particles and organisms adhering to algal surface and then dried in an oven at $60-70{ }^{\circ} \mathrm{C}$. The dried samples pulverized in a mill and sieved to provide particle size homogeneity using a 100 mesh sieve. From each separate sample, $0.5 \mathrm{~g}$ was weighed into a 100 porcelain crucible; ignite at $500{ }^{\circ} \mathrm{C}$ in a muffle furnace overnight. After cooling, the ashed samples dissolved in $5 \mathrm{ml} 20 \% \mathrm{HCl}$, filtered and completed to $50 \mathrm{ml}$ with distilled water, as described by AOAC (1990). Atomic Absorption Spectrophotometer 
(Model Thermo Electron Corporation) instrument was used to detect metals concentrations which were expressed as $\mu \mathrm{g} / \mathrm{g}$ dry wt in algae tissues and $\mu \mathrm{g} / \mathrm{l}$ in water samples.

b) Water

Metals concentration in filtered water samples were measured after digestion with conc. $\mathrm{HNO}_{3}$ and $\mathrm{HCl}$ according to EPA (1992).

Bioconcentration of metals in tissues of seaweed can be described by a bioconcentration factor $(\mathrm{BCF})$, which is the ratio of the chemical concentration in an organism $\left(\mathrm{C}_{\mathrm{B}}\right)$ (mg of chemical per $\mathrm{kg}$ of organism to the concentration in water $\left(\mathrm{C}_{\mathrm{w}}\right)$ ( $\mathrm{mg}$ of chemical per liter of water):

$\mathbf{B C F}=\mathbf{C}_{\mathbf{B}} / \mathbf{C}_{\mathbf{w}}$ (Gobas and Morrison, 2000).

\section{Statistical analysis}

Two-way ANOVA was employed to evaluate the variability of the concentration of each metal with respect to different seasons and sites. The interelemental relationships were performed through Pearson's correlation coefficient matrix. Significant differences are stated at $\mathrm{P}<0.05$ (Bailey, 1981).

\section{RESULTS AND DISCUSSION}

\section{Metals in seaweed}

The seasonal variations in the concentrations of $\mathrm{Fe}, \mathrm{Mn}, \mathrm{Zn}, \mathrm{Cu}, \mathrm{Cd}$ and $\mathrm{Pb}$ in seaweed (Ulva sp.) collected from Ras Al-Tin and Al-Muntazah region on the shore of the Mediterranean coast are shown in Table (1) and Figure (2). Only, Mn, Zn and $\mathrm{Cu}$ showed significant $(\mathrm{P}<0.05)$ variations in concentration with respect to seasons. Among the metal concentrations, Fe showed the highest average $\left(687.60 \mu \mathrm{g} \mathrm{g}^{-1} \mathrm{dw}\right)$

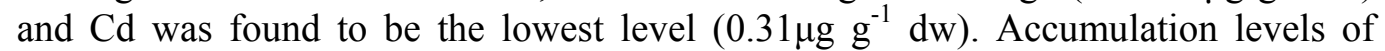
heavy metals have been detected in the order $\mathrm{Fe}>\mathrm{Mn}>\mathrm{Zn}>\mathrm{Cu}>\mathrm{Pb}>\mathrm{Cd}$. This order was also obtained in Ulva sp. by Alp et al. (2012). As for essential metals, the concentration order may correspond to their biological role in algal tissues (Munda and Hudnik, 1986; Dadolahi et al., 2011).

In Ulva sp., the highest Fe concentrations were obtained in spring and autumn. The highest concentrations of Fe observed in autumn was similarly to that observed in Greece by Haritonidis and Malea (1999) and in Spain by Villares et al. (2002), when biomass is minimal. However, Misheer et al. (2006), in South Africa found the highest values in winter and the lowest during summer and autumn. Pérez et al. (2012) recorded high levels of Fe in Ulva sp. and declared that this algae is an excellent source of these metals. The possibility that seaweeds may have been absorbed Fe present in fine sediment particles (Giusti, 2001). Some species are able to absorb elements directly from sediment (through thallus and rhizoids, in which metal concentrations are much higher than in the water column) (Zbikowski et al., 2006). In this study, the algae samples collected were attached to sand and rocks distributed along the coast.

Manganese concentrations exhibit higher values in summer, while the lowest one detected in winter and this may be related to anthropogenic discharges, including domestic, industrial and agricultural discharges (Rybak et al., 2013).

The variation of the $\mathrm{Zn}$ concentration follows the pattern in which maximum concentrations occur in autumn and winter, followed by a decrease in spring and summer. A significant seasonal and spatial variation is observed all year long $(p<0.05)$ (Table 3 and Fig. 2). Pérez et al. (2012) observed the highest concentrations of $\mathrm{Zn}$ in autumn and winter. Similar results were reported by Villares et al. in 2002 
(18 $\left.\mu \mathrm{g} \mathrm{g}^{-1} \mathrm{dw}\right)$, by Haritonidis and Malea, $1999\left(16.9 \mu \mathrm{g} \mathrm{g}^{-1} \mathrm{dw}\right)$ and Pérez et al., 2012 $\left(1.3-31.3 \mu \mathrm{g} \mathrm{g}^{-1} \mathrm{dw}\right)$. Higher values than those were reported by Caliceti et al. (2002) in Italy with $64 \mu \mathrm{g} \mathrm{g}^{-1} \mathrm{dw}$; and lower values were reported by Chaudhuri et al. (2007) in USA, which fluctuated between 6 and $12 \mu \mathrm{g} \mathrm{g}^{-1} \mathrm{dw}$. Finally, it is worth noting that Zn concentrations for Ulva sp. were reported to vary seasonally (Brown et al., 1999), with higher figures in winter than in spring or summer. It has been reported that the average zinc residues in plants collected from polluted waters are within the range of 100 to $500 \mu \mathrm{g} \mathrm{g}^{-1} \mathrm{dw}$ (Moore and Ramamoorthy, 1984). Applying these guidelines to the present study, it could be inferred that the study area are uncontaminated sites with respect to $\mathrm{Zn}$.

$\mathrm{Cu}$ concentrations showed significant differences among seasons and the sampling sites $(\mathrm{p}<0.05)$, for Ulva spp. Its levels decrease in spring and summer and increase in winter and autumn. Favero et al., 1996) mentioned that essential metal $(\mathrm{Cu})$ levels gradually decrease from spring to summer. This metal would be actively uptaken by algal tissues in the spring proliferation. Topcluogu et al. (2010) mentioned that, industrials effluents from the extensive oil production, high traffic shipping, loading and transport facilities off coasts could act as source of $\mathrm{Cu}$ pollution. According to Giusti (2001) and Caliceti et al. (2002) copper contamination is associated with algal levels of $>20.0 \mu \mathrm{g} \mathrm{g}^{-1} \mathrm{dw}$. Similarly, (Sawidis et al., 2001) have considered that a range of 20 to $70 \mu \mathrm{g} \mathrm{g}^{-1} \mathrm{dw}$ in green macroalgae as a characteristic of contaminated sites. So, this area is uncontaminated with copper.

The competition between metals for algal sites could decrease the accumulation of $\mathrm{Cd}$ and $\mathrm{Pb}$ which exhibited lower concentration levels in water or which are present in less available forms (e.g. Cd) (Dadolahi et al., 2011). Foster (1976) reported that elevated $\mathrm{Zn}$ concentrations inhibited $\mathrm{Cd}$ uptake by seaweeds due to competition for binding sites. It has been reported that algal runs samples containing lower than $2 \mu \mathrm{g}$ $\mathrm{g}^{-1} \mathrm{dw}$ of cadmium can be considered not polluted (Lozano et al., 2003). In algae collected from the two sites, cadmium concentrations varied between 0.27 and 0.35 $\mu \mathrm{g} \mathrm{g}^{-1} \mathrm{dw}$. So, there is no cadmium pollution problem in the study area. The poor accumulation of cadmium seems to be a feature typical for all species of Ulva (Rybak et al., 2012). High levels of $\mathrm{Pb}$ in alga of study area could be attributed to combustion of fossil fuels and oil pollution (Dadolahi et al., 2011). Also, potential contamination from sediment particles appears theoretically possible for Pb (Giusti, 2001). A concentration of $<10 \mu \mathrm{g} \mathrm{g}^{-1} \mathrm{dw}$. has been considered as a border line between contaminated and uncontaminated species (Lozano et al., 2003). We can conclude that the lead contents of the algal specimen studied were within the expected limits of uncontaminated areas.

Increased $\mathrm{Cu}, \mathrm{Cd}$ and $\mathrm{Pb}$ in winter and autumn may be as a result of inputs of materials via atmosphere in marine environment of the Alexandria shore which are probably significant due to different oil industry activities and high shipping traffic. There is evidence of seasonal variations of trace metal concentration in Ulva sp. (Favero et al., 1996; Caliceti et al., 2002; Villares et al., 2002; Misheer, 2006; Pérez et al., 2012), especially for $\mathrm{Mn}, \mathrm{Zn}$ and $\mathrm{Cu}$.

$\mathrm{Fe}, \mathrm{Mn}, \mathrm{Zn}$ and $\mathrm{Cu}$ showed significant $(\mathrm{P}<0.05)$ variations between the two sites. In general, the highest concentrations of $\mathrm{Fe}, \mathrm{Mn}$ and $\mathrm{Cd}$ being recorded at $\mathrm{Al}$ Muntazah region (B), whereas $\mathrm{Cu}, \mathrm{Zn}$ and $\mathrm{Pb}$ highly accumulated in algae from Ras Al-Tin area (A) (Table 1 and Fig. 2). 
The seaweed as bioindicator of metal pollution in the Mediterranean Coast Alexandria Egypt 61

Table 1: Seasonal mean $( \pm \mathrm{SE})$ of heavy metals concentration $\left(\mu \mathrm{g} \mathrm{g}^{-1}\right.$ dry weight $)$ in Ulva sp. during the four sampling seasons from Ras Al-Tin (A) and Al-Mountazah (B).

\begin{tabular}{|c|c|c|c|c|c|c|c|c|c|c|c|c|}
\hline \multirow[t]{3}{*}{ Season } & \multicolumn{12}{|l|}{ Metals } \\
\hline & \multicolumn{2}{|c|}{$\mathrm{Fe}$} & \multicolumn{2}{|c|}{$\mathrm{Mn}$} & \multicolumn{2}{|c|}{$\mathrm{Zn}$} & \multicolumn{2}{|c|}{$\mathrm{Cu}$} & \multicolumn{2}{|c|}{$\mathrm{Cd}$} & \multicolumn{2}{|c|}{$\mathrm{Pb}$} \\
\hline & A & B & A & B & A & B & A & B & $\mathrm{A}$ & B & $\mathrm{A}$ & B \\
\hline \multirow{2}{*}{ Winter } & 516.2 & 550.7 & 9.46 & 9.60 & 15.12 & 12.55 & 17.20 & 7.39 & 0.62 & 0.48 & 6.03 & 4.09 \\
\hline & \pm 96.0 & \pm 53.6 & \pm 0.68 & \pm 0.90 & \pm 1.76 & \pm 1.02 & \pm 1.29 & \pm 0.58 & \pm 0.22 & \pm 0.19 & \pm 0.71 & \pm 0.26 \\
\hline \multirow{2}{*}{ Spring } & 513.3 & 891.0 & 21.41 & 28.27 & 9.34 & 9.89 & 12.48 & 10.20 & 0.085 & 0.36 & 4.04 & 4.86 \\
\hline & \pm 39.7 & \pm 145.7 & \pm 4.93 & \pm 0.80 & \pm 1.52 & \pm 0.01 & \pm 0.09 & \pm 0.72 & \pm 0.03 & \pm 0.19 & \pm 0.45 & \pm 0.28 \\
\hline \multirow{2}{*}{ Summer } & 662.9 & 696.3 & 21.65 & 51.47 & 9.30 & 9.73 & 11.12 & 7.14 & 0.207 & 0.21 & 5.34 & 4.22 \\
\hline & \pm 88.5 & \pm 186.6 & \pm 2.44 & \pm 14.78 & \pm 0.71 & \pm 0.82 & \pm 0.16 & \pm 0.43 & \pm 0.02 & \pm 0.10 & \pm 1.41 & \pm 0.39 \\
\hline \multirow{2}{*}{ Autumn } & 719.3 & 951.2 & 13.02 & 25.79 & 21.01 & 14.09 & 16.45 & 11.67 & 0.16 & 0.34 & 6.31 & 4.75 \\
\hline & \pm 101.7 & \pm 49.8 & \pm 0.35 & \pm 4.33 & \pm 0.36 & \pm 0.08 & \pm 0.22 & \pm 0.25 & \pm 0.01 & \pm 0.07 & \pm 0.58 & \pm 0.44 \\
\hline \multirow{2}{*}{ Mean } & 602.9 & 772.3 & 16.39 & 28.78 & 13.69 & 11.57 & 14.31 & 9.10 & 0.27 & 0.35 & 5.43 & 4.48 \\
\hline & \pm 60.27 & \pm 105.9 & \pm 3.53 & \pm 6.45 & \pm 3.22 & \pm 1.23 & \pm 1.71 & \pm 1.27 & \pm 0.13 & \pm 0.06 & \pm 0.58 & \pm 0.22 \\
\hline O. M." & 687.60 & & 22.59 & & 12.63 & & 11.71 & & 0.31 & & 4.96 & \\
\hline \multicolumn{13}{|c|}{ Two-way ANOVA (P-value) } \\
\hline Season & \multicolumn{2}{|l|}{0.0801} & \multicolumn{2}{|c|}{$0.0023 * *$} & \multicolumn{2}{|c|}{$0.0000 * * *$} & \multicolumn{2}{|c|}{$0.0000 * * *$} & \multicolumn{2}{|l|}{0.0863} & \multicolumn{2}{|l|}{0.4406} \\
\hline Site & \multicolumn{2}{|l|}{$0.0386 *$} & \multicolumn{2}{|c|}{$0.0081 * *$} & \multicolumn{2}{|c|}{$0.0075 * *$} & \multicolumn{2}{|c|}{$0.0000 * * *$} & \multicolumn{2}{|l|}{0.4665} & \multicolumn{2}{|l|}{0.0592} \\
\hline
\end{tabular}

$*, * *$ and $* * *$ are significant at $(\mathrm{P}<0.05),(\mathrm{P}<0.01)$ and $(\mathrm{P}<0.001)$, respectively. O. M." : overall mean of the study area.
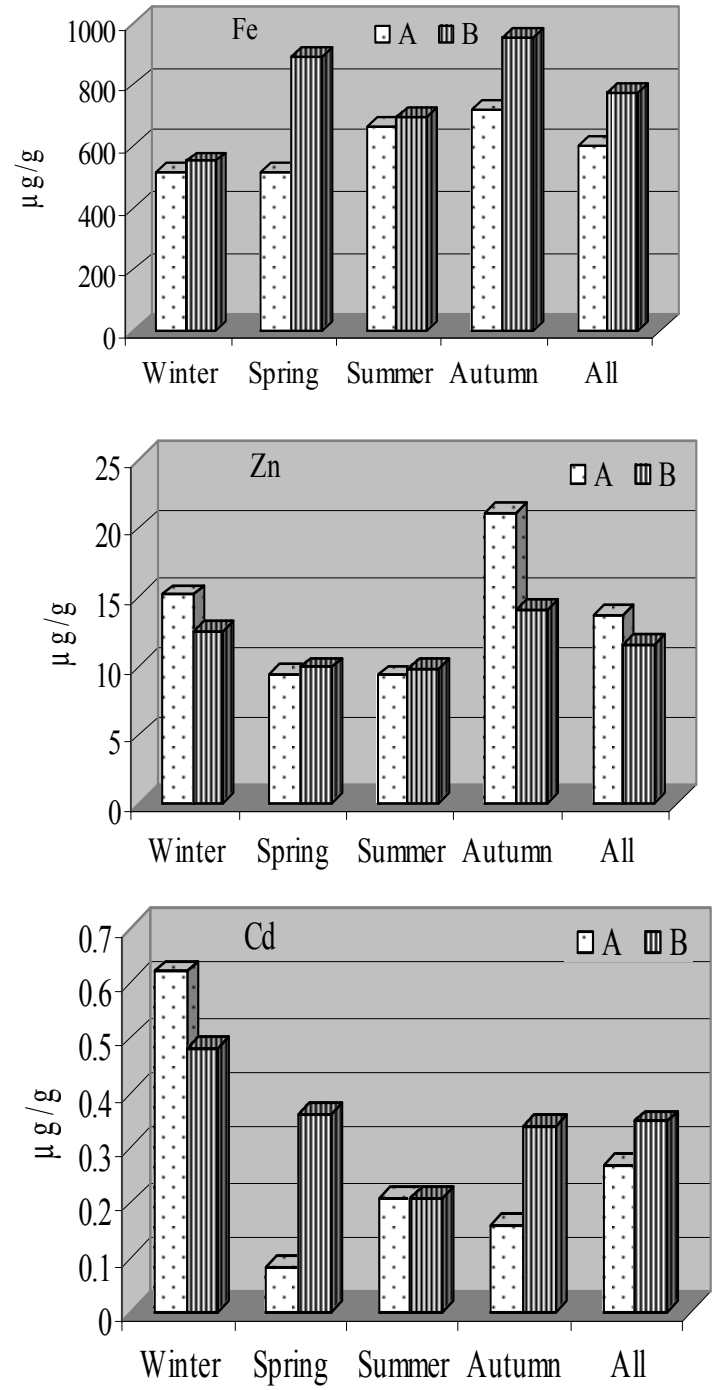
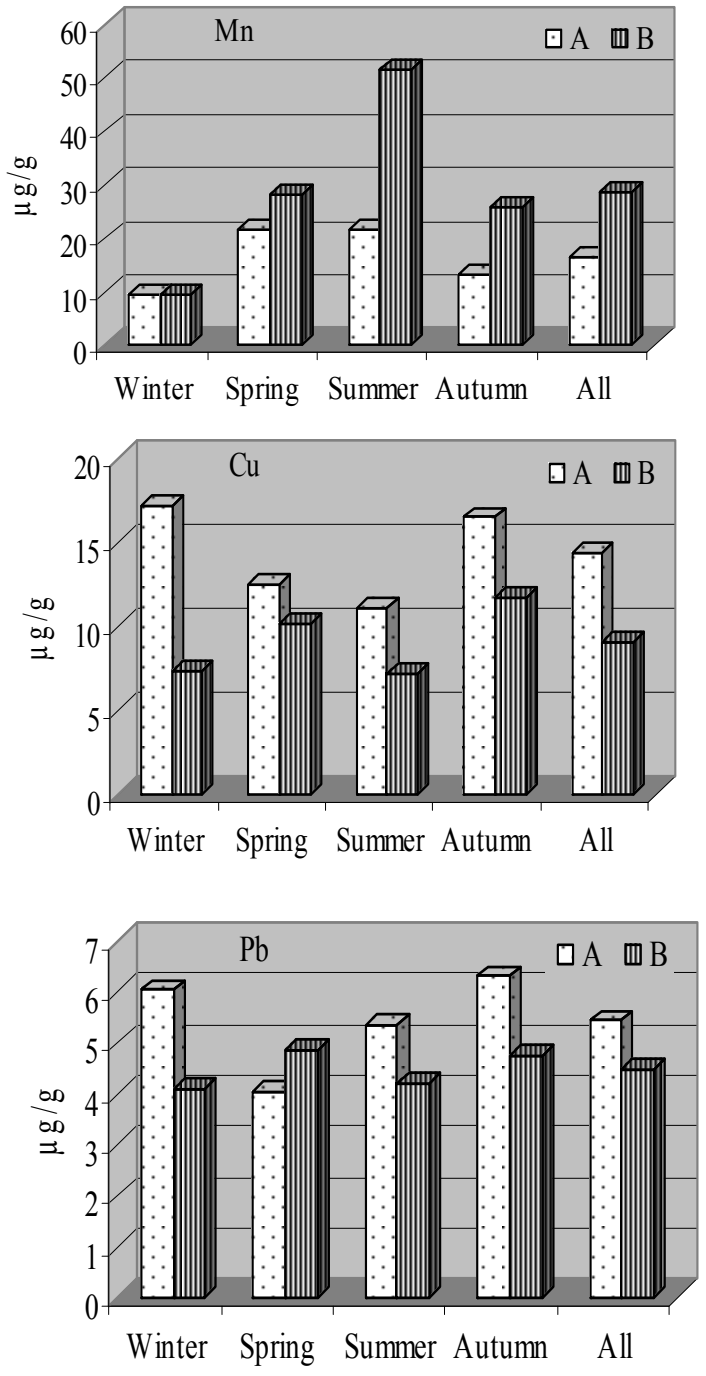

Fig. 2: Metals concentration ( $\mu \mathrm{g} \mathrm{g}^{-1}$ dry wt.) in Ulva sp. collected from Ras Al-Tin (A) and AlMountazah (B), Mediterranean coast, Alexandria region, during the four seasons. 
Abdallah and Abdallah, (2008) showed that the metal variation in species from different sampling sites may be related to factors such as tidal range, temperature, salinity, dissolved nutrients, type of tissue, age of algae, its nutritional history and the geological structure of the study area. Forsberg et al. (1988) showed that the dynamic factors could affect the metals uptake in seaweed.

A comparison of the present results with data reported for similar algal species from other Mediterranean marine environment in Egypt and other regions (Table 2), suggest that the heavy metal concentrations showed higher and lower than the others studies. Studied metals are lower in the Egyptian Coast Mediterranean Sea algae than the Turkish Coast algae (Topçuoğlu et al., 2010) for Fe, Mn and Zn; Italy Coast (Caliceti et al., 2002) for all metals except Cd and Spain Coast (Villares et al., 2001) for $\mathrm{Mn}$ and $\mathrm{Zn}$. Abdallah and Abdallah (2008) recorded high concentrations of Mn, $\mathrm{Zn}, \mathrm{Cu}$ and $\mathrm{Cd}$ in Ulva sp. in the coast of Mediterranean Sea, Egypt. In addition, $\mathrm{Cu}$, $\mathrm{Cd}$ and $\mathrm{Pb}$ (except $\mathrm{Pb}$ in Abdallah, 2010) in this study are higher in Ulva sp. than that recorded for the same species by Abdallah, 2010; Topçuoğlu et al., 2010). On the other hand, other references recorded lower metals concentrations than the present study, are also delineated.

Table 2: Comparison of heavy metals concentrations (ug $\mathrm{g}^{-1}$ dry wt.) of Ulva sp. in the present study and other studies at the Mediterranean Sea coast.

\begin{tabular}{lccccccc}
\hline \multicolumn{1}{c}{ Reference } & Location & $\mathrm{Fe}$ & $\mathrm{Mn}$ & $\mathrm{Zn}$ & $\mathrm{Cu}$ & $\mathrm{Cd}$ & $\mathrm{Pb}$ \\
\hline $\begin{array}{l}\text { Abdallah and } \\
\text { Abdallah (2008) }\end{array}$ & Egypt & $514.55 \pm 2.1$ & $73.95 \pm 4.8$ & $63.10 \pm 3.2$ & $14.52 \pm 4.7$ & $1.84 \pm 0.93$ & - \\
Abdallah (2010) & Egypt & - & $8.07-92.1$ & $10.0-97.5$ & $2.0-8.61$ & $0.18-1.6$ & $4.5-6.65$ \\
$\begin{array}{l}\text { Topçuoğlu et } \text { al. } \\
\text { (2010) }\end{array}$ & Turky & $3195.1 \pm 12.3$ & $68.02 \pm 0.51$ & $76.37 \pm 1.68$ & $7.93 \pm 0.11$ & $<0.02$ & $<0.10$ \\
Alp et al. (2012) & Turky & $94.52-360.51$ & $3.07-11.17$ & $3.38-5.46$ & $0.22-2.27$ & $0.02-0.05$ & $0.70-1.11$ \\
Villares (2001) & Spain & 365.0 & 37.5 & 23.6 & 7.84 & - & - \\
$\begin{array}{l}\text { Caliceti et al. } \\
(2002) \quad \text { Italy }\end{array}$ & $1033 \pm 564$ & - & $64.0 \pm 55.0$ & $13 \pm 7.0$ & $0.2 \pm 0.0$ & $7.3 \pm 6.4$ \\
Present study & Egypt & $602.9-772.3$ & $16.39-28.78$ & $11.57-13.69$ & $9.10-14.3$ & $0.27-0.35$ & $4.48-5.43$ \\
\hline
\end{tabular}

\section{Heavy metal distributions in Water}

The seasonal mean of different metals concentration in seawater are shown in Table (3) and Figure (3). Metal levels exhibited the same pattern across the two sites: $\mathrm{Fe}>\mathrm{Zn}>\mathrm{Mn}>\mathrm{Cu}>\mathrm{Pb}>\mathrm{Cd}$. Iron (Fe) distribution revealed high levels at site A (134 $\mu \mathrm{gl}^{-}$ $\left.{ }^{1}\right)$ and decreased at site $\mathrm{B}\left(131 \mu \mathrm{g}^{-1}\right)$. In general, Fe concentration revealed irregular variation among seasons. Manganese $(\mathrm{Mn})$ varied between 4.5 and $7.5 \mu \mathrm{g} \mathrm{l}^{-1}$ at Ras Al-Tin to 5.9 and $7.7 \mu \mathrm{g} \mathrm{l}^{-1}$ at Al-Mountazah. The mean value tend to be increased slightly at site $\mathrm{B}\left(6.6 \mu \mathrm{g} \mathrm{1^{-1 }}\right)$ than in site $\mathrm{A}\left(6.0 \mu \mathrm{g}^{-1}\right)$. The highest values of Fe and $\mathrm{Mn}$ were recorded during winter and autumn.

The results revealed wide variation in the distribution of zinc concentrations. $\mathrm{Zn}$ concentration varied between 4.5 and $7.0 \mu \mathrm{g} \mathrm{l}^{-1}$ at site A and 3.8 and $11.5 \mu \mathrm{g} \mathrm{l^{-1 }}$ at site $\mathrm{B}$, with the highest concentrations during winter. The total average $\mathrm{Zn}$ content ranged from $5.8 \mu \mathrm{g} \mathrm{l}^{-1}$ at site A and $7.1 \mu \mathrm{g} \mathrm{l^{-1 }}$ at site B. Copper concentration is remarkable in surface water; the values tend to be higher at the site $\mathrm{A}\left(3.2-4.9 \mu \mathrm{g}^{-1}\right)$ than site $\mathrm{B}$ values (3.4-4.3 $\mu \mathrm{g} \mathrm{l}^{-1}$ ). In general, the total average values of $\mathrm{Cu}$ ranged from $4.0 \mu \mathrm{g} \mathrm{l}^{-}$ ${ }^{1}$ at site $\mathrm{B}$ to $4.2 \mu \mathrm{g} \mathrm{l}^{-1}$ at site A (Table 3 ) with the maximum value in winter.

The lead $(\mathrm{Pb})$ concentrations were generally increased at winter and remained relatively low at summer (Table 3 and Fig. 3). $\mathrm{Pb}$ concentrations in the study area ranged from 3.4 to $3.9 \mu \mathrm{g} \mathrm{l}^{-1}$ at site $\mathrm{A}$ and 3.4 to $3.9 \mu \mathrm{g}^{-1} ; 1.5$ to $7.8 \mu \mathrm{g} \mathrm{l}^{-1}$ at site $\mathrm{B}$. 
The average values of $\mathrm{Pb}$ concentration ranged from 3.8 to $4.8 \mu \mathrm{g}^{-1}$ at site $\mathrm{A}$ and site $\mathrm{B}$, respectively. Table (3) and Figure (3) shows the concentration of cadmium (Cd) is not detected at the two sites during the study period.

Table 3. Seasonal mean ( \pm SE) of heavy metals concentration in water of Ras-Al-Tin (A) and AlMountazah (B) on shore of the Mediterranean coast, Alexandria region.

\begin{tabular}{|c|c|c|c|c|c|c|c|c|c|c|c|c|}
\hline \multirow{3}{*}{ Season } & \multicolumn{12}{|c|}{ Metals } \\
\hline & \multicolumn{2}{|c|}{$\mathrm{Fe}$} & \multicolumn{2}{|c|}{$\mathrm{Mn}$} & \multicolumn{2}{|c|}{$\mathrm{Zn}$} & \multicolumn{2}{|c|}{$\mathrm{Cu}$} & \multicolumn{2}{|c|}{$\mathrm{Cd}$} & \multicolumn{2}{|c|}{$\mathrm{Pb}$} \\
\hline & A & $\mathrm{B}$ & $\mathrm{A}$ & B & $\mathrm{A}$ & B & $\bar{A}$ & B & $\bar{A}$ & B & $\bar{A}$ & $\mathrm{~B}$ \\
\hline \multirow{2}{*}{ Winter } & 157 & 170 & 6.9 & 7.7 & 7.0 & 11.5 & 4.9 & 4.3 & ND & ND & 4.0 & 7.8 \\
\hline & \pm 11 & \pm 17 & \pm 1.4 & \pm 1.3 & \pm 1.5 & \pm 2.1 & \pm 1.0 & \pm 1.0 & \pm 0.0 & \pm 0.0 & \pm 0.9 & \pm 1.4 \\
\hline \multirow{2}{*}{ Spring } & 121 & 140 & 4.5 & 5.9 & 5.3 & 6.2 & 4.1 & 4.2 & ND & ND & 3.7 & 5.9 \\
\hline & \pm 7 & \pm 19 & \pm 1.1 & \pm 1.3 & \pm 1.2 & \pm 1.3 & \pm 1.0 & \pm 1.0 & \pm 0.0 & \pm 0.0 & \pm 0.7 & \pm 1.1 \\
\hline \multirow{2}{*}{ Summer } & 82 & 91 & 5.2 & 6.1 & 4.5 & 3.8 & 4.4 & 4.0 & ND & ND & 3.4 & 1.5 \\
\hline & \pm 6 & \pm 11 & \pm 1.2 & \pm 1.5 & \pm 1.1 & \pm 0.8 & \pm 1.0 & \pm 0.7 & \pm 0.0 & \pm 0.0 & \pm 0.8 & \pm 0.3 \\
\hline \multirow{2}{*}{ Autumn } & 176 & 122 & 7.5 & 6.6 & 6.2 & 6.8 & 3.2 & 3.4 & ND & ND & 3.9 & 3.9 \\
\hline & \pm 10 & \pm 13 & \pm 1.2 & \pm 1.5 & \pm 1.4 & \pm 1.2 & \pm 0.6 & \pm 0.7 & \pm 0.0 & \pm 0.0 & \pm 0.8 & \pm 0.7 \\
\hline \multirow{2}{*}{ Mean } & 134 & 130.8 & 6.0 & 6.6 & 5.8 & 7.1 & 4.2 & 4.0 & $\mathrm{ND}$ & ND & 3.8 & 4.8 \\
\hline & \pm 24 & \pm 19 & \pm 1.3 & \pm 1.4 & \pm 1.3 & \pm 1.5 & \pm 1.0 & \pm 0.8 & \pm 0.0 & \pm 0.0 & \pm 0.7 & \pm 1.0 \\
\hline O. M." & \multicolumn{2}{|c|}{132} & \multicolumn{2}{|c|}{6.3} & \multicolumn{2}{|c|}{6.5} & \multicolumn{2}{|c|}{4.1} & \multicolumn{2}{|c|}{ ND } & \multicolumn{2}{|c|}{4.3} \\
\hline \multicolumn{13}{|c|}{ Two-way ANOVA (P-value) } \\
\hline Season & \multirow{2}{*}{\multicolumn{2}{|c|}{$\begin{array}{c}0.0000 * * * \\
0.1019\end{array}$}} & \multirow{2}{*}{\multicolumn{2}{|c|}{$\begin{array}{c}0.5363 \\
0.6513\end{array}$}} & \multirow{2}{*}{\multicolumn{2}{|c|}{$\begin{array}{c}0.0216 * \\
0.2278\end{array}$}} & \multicolumn{2}{|c|}{0.5217} & \multicolumn{2}{|c|}{ ND } & \multicolumn{2}{|c|}{$0.0487 *$} \\
\hline Site & & & & & & & \multicolumn{2}{|c|}{0.7761} & \multicolumn{2}{|c|}{ ND } & \multicolumn{2}{|c|}{0.1627} \\
\hline
\end{tabular}

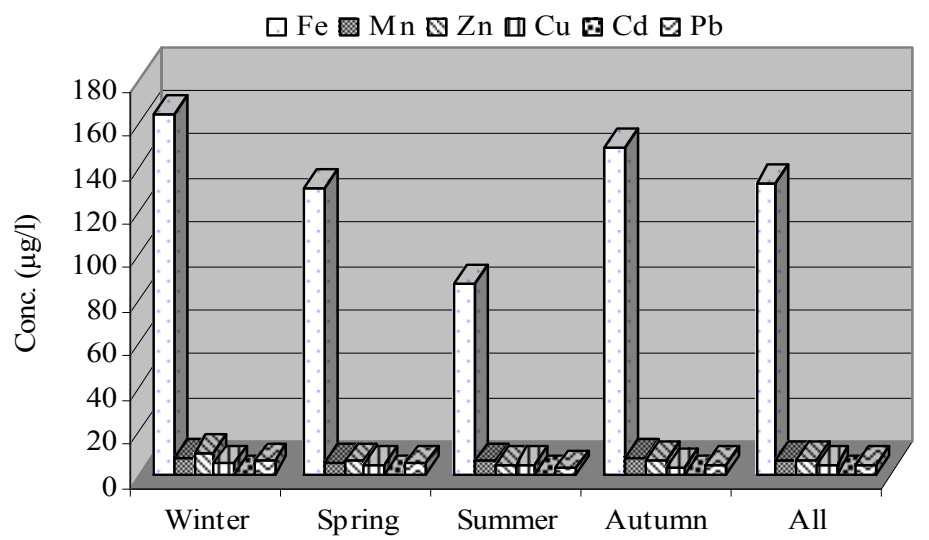

Fig. 3: Seasonal variations of metals concentration $\left(\mu \mathrm{g} \mathrm{l}^{-1}\right)$ in water of the Mediterranean coast during the four seasons.

Metals concentrations varied significantly $(\mathrm{P}<0.05)$ through seasons (except $\mathrm{Mn}$ and $\mathrm{Cu}$ ) (Table 3). On the other hand, no significant difference was recorded between the sites. This pattern may be as a result of similar conditions affecting these sites as local anthropogenic sources, sediments and/or the release of metals into the water as a freshwater and seawater combination (Perez et al., 2003). The effect of wind as mentioned earlier not only increase the transfer of soil particles into the sea, but it also caused water agitation and mixing of sediment particles, both of which may increase the heavy metal loads in the water. Spring and summer showed the lowest values than other seasons. This may be due to the contribution of phytoplankton biomass in these seasons (El-Gohary et al., 2012). Faragallah et al. (2009) suggested that the biological uptake may the main factor controlling the removal mechanisms of dissolved heavy metals. They found significant negative relationship between dissolved $\mathrm{Cu}, \mathrm{Fe}$ and $\mathrm{Zn}$ content and the values of chl-a concentration and $\mathrm{pH}$. 
Table (4) shows that concentrations of heavy metals in seawater increased or decreased as compared to other studies on Mediterranean coastal waters, Egypt. Elevated values of $\mathrm{Fe}$ in water comparing with those previously reported may be explained as a result of the effect of the agitation of the bottom sediments which have relatively high metal concentrations (Faragallah et al., 2009) as samples collected on shore. Generally, the levels of all studied metals in the two sites are still below the background values of the natural water recommended by WHO (2011) for surface or natural water.

Table 4: Comparison of heavy metals concentration $\left(\mu \mathrm{g} \mathrm{l}^{-1}\right)$ in the present study and other references on the Mediterranean Sea water in Egypt.

\begin{tabular}{lllllll}
\hline Reference & \multicolumn{2}{l}{ Metals } & & & & \\
\cline { 2 - 7 } & $\mathrm{Fe}$ & $\mathrm{Mn}$ & $\mathrm{Zn}$ & $\mathrm{Cu}$ & $\mathrm{Cd}$ & $\mathrm{Pb}$ \\
El-Nady (1996) & - & - & $1.0-39.8$ & $0.6-12.2$ & $\mathrm{~N} . \mathrm{D}-2.5$ & $0.4-18.8$ \\
Okbah and Nasr, 2006 & $11.92-30.45$ & $5.79-17.36$ & $0.87-7.80$ & $0.40-1.87$ & - & $1.53-10.31$ \\
Abdallah, 2008 & $27.21-70.91$ & $2.7-31.28$ & $20.79-59.29$ & $3.69-4.90$ & $0.66-6.45$ & $2.65-26.14$ \\
Faragallah et al. , 2009 & $28.66-43.73$ & - & $25.94-38.22$ & $2.0-6.74$ & - & $2.93-4.33$ \\
El-Gohary et al. , 2012 & - & - & $4.67-31.39$ & $3.04-6.08$ & $0.57-1.26$ & $15.96-22.64$ \\
Present study & 132 & 6.3 & 6.5 & 4.1 & $\mathrm{ND}$ & 4.3 \\
*WHO (2011) & $0.5-50.0$ & $0.1-0.4$ & $0.01-0.05$ & 1.0 & 0.003 & 0.01 \\
\hline
\end{tabular}

*Metals concentration in natural water $(\mathrm{mg} / \mathrm{l})$.

The bioconcentration factor (BCF) provides an index of the ability of the plant to accumulate metal with respect to the metal concentration in the substrate. The overall consistency in metal uptake by Ulva sp. at sampled sites was reconfirmed by its $\mathrm{BCF}$ values (Fig. 4). These values were varied in orders of magnitude and location and decreased as for $\mathrm{Fe}>\mathrm{Mn}>\mathrm{Cu}>\mathrm{Zn}>\mathrm{Pb}>\mathrm{Cd}$. Ulva sp. showed a consistent, high affinity for $\mathrm{Fe}, \mathrm{Mn}$ and $\mathrm{Cu}$ and to less extent for $\mathrm{Cd}$ and $\mathrm{Pb}$ in the two sites. This phenomenon indicates that this seaweed has a bioavailability to accumulate metals from the surrounding medium and can suggest using it as a good bioindicator for the presence of essential and highly toxic metals. Also, it is clear that $\mathrm{Fe}, \mathrm{Mn}$ and $\mathrm{Cd}$ more accumulated in algae collected from site II, whereas $\mathrm{Zn}, \mathrm{Cu}$ and $\mathrm{Pb}$ highly concentrated in algae tissues at site I.

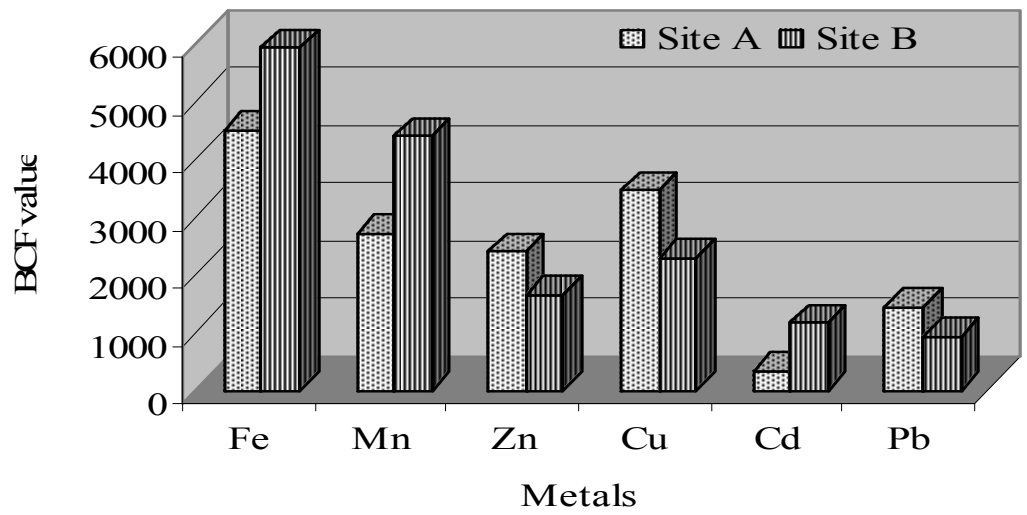

Fig. 4: Bioconcentration factors (BCF) of metals in studied sites, Ras-Al-Tin (A) and Al-Mountazah (B).

The high accumulation of metals in Ulva sp. reflect the high bioavailability of these metals in the study area, and the capacity of the alga to take them up and 
sequencer them. This coincides with Shanmugam et al. (2012) who stated that seaweeds are excellent agents of filtering the metals like iron, zinc, copper and cadmium from seawater and accumulate them in their body cells 4,000-20,000 times more than the surrounding water.

The correlation coefficient matrix between heavy metal concentrations in Ulva sp. tissues showed some positive significant correlations for some pairs of metals. There were positive relationships $(\mathrm{P}<0.05)$ between $\mathrm{Fe}$ and $\mathrm{Mn} ; \mathrm{Mn}$ and $\mathrm{Cu} ; \mathrm{Zn}$ and $\mathrm{Cu} ; \mathrm{Zn}$ and $\mathrm{Pb} ; \mathrm{Cu}$ and $\mathrm{Pb}$ and finally no significant correlations were found $(\mathrm{P}>0.05)$ between other paired of metals (Table 5). These results can show that the six elements measured in the present study having similar sources and this may be related to geographical structure of this area as well as due to anthropogenic activities caused by industrial effluents and domestic sewage. Statistically significant correlations were observed between $\mathrm{Cu}$ and $\mathrm{Pb}$ concentrations and Fe-Mn (Favero et al., 1996). The synergistic interaction of $\mathrm{Pb}$ with $\mathrm{Zn}$ in Ulva compressa was observed (Dadolahi et al., 2011). In our study, the significant positive correlation between $\mathrm{Zn}$ and $\mathrm{Cu}$ in seaweed rules out large competition effects between these two metals. Similar results were recorded by (Giusti, 2001).

Table 5: Correlation coefficient matrix (r) between concentrations of paired metals in green macroalgae (Ulva sp.)

\begin{tabular}{ccccccc}
\hline Metal & $\mathrm{Fe}$ & $\mathrm{Mn}$ & $\mathrm{Zn}$ & $\mathrm{Cu}$ & $\mathrm{Cd}$ & $\mathrm{Pb}$ \\
\hline $\mathrm{Fe}$ & 1.0 & & & & & \\
$\mathrm{Mn}$ & $0.0261^{*}$ & 1.0 & & & & \\
$\mathrm{Zn}$ & 0.4942 & 0.1192 & 1.0 & & & \\
$\mathrm{Cu}$ & 0.4830 & $0.0305^{*}$ & $0.0009^{* * *}$ & 1.0 & & \\
$\mathrm{Cd}$ & 0.8958 & 0.5100 & 0.2629 & 0.4450 & 1.0 & \\
$\mathrm{~Pb}$ & 0.6261 & 0.4429 & $0.0031^{* *}$ & $0.0044^{* *}$ & 0.0714 & 1.0 \\
$* * *$ and $* * *$ & are significant correlation at $(\mathrm{P}<0.05),(\mathrm{P}<0.01)$ and $(\mathrm{P}<0.001)$, respectively.
\end{tabular}

\section{CONCLUSION}

The average metal concentrations for seaweeds from the two shoreline areas (Ras Al-Tin and Al-Muntazah) were different. Fe, $\mathrm{Mn}, \mathrm{Cu}$ and $\mathrm{Zn}$ showed the greater spatial (except Fe) and temporal differences $(\mathrm{P}<0.05)$. The results showed that the studied area in Mediterranean coast in Egypt not faced heavy metals pollution. Ulva sp. plays an important role as a bioindicator for heavy metals contamination in seawater. This conclusion was supported by the thousand times higher levels of metals concentrations observed in the Ulva than in water from the same sites

\section{REFERENCES}

Abdallah, M. A. (2008). Trace metal Behavior in Mediterranean-Climate Coastal Bay: El-mex Bay, Egypt and its Coastal Environment. Global J. Environ. Rese., 2 (1): 23-29.

Abdallah M. A. (2010). Heavy metal monitoring in marine seaweeds from the southeastern Mediterranean Sea of the Egyptian coast, 2006-2009. Proceedings of the $4^{\text {th }}$ Mediterranean Symposium on marine vegetation YasmineHammamet, 2-4 December 2010.

Abdallah, M. and Abdallah, M. (2008). Biomonitoring study of heavy metals in biota and sediments in the South Eastern coast of Mediterranean Sea. Environment and Monitoring Assessment, 146(1-3): 139-145. 
Alp, M.T.; Ozbay, O. and Sungur, M. A. (2012). Determination of Heavy Metal Levels in Sediment and Macroalgae (Ulva Sp. And Enteromorpha Sp.) on the Mersin Coast. Ekoloji 21 (82): 47-55.

A.O.A.C. 1990. Association of Official Analytical Chemists. Official Methods of Analysis. 15 $5^{\text {th }}$ ed. "Atomic Absorption Method for metals". Washington, D.C.

Apaydn, G.; Aylıkc V.; Cengiz, E.; Saydam, M.; Küp, N.; Tıraşoğlu, E. (2010). Analysis of Metal Contents of Seaweed (Ulva lactuca) from Istanbul, Turkey by EDXRF. Turk. J. Fish. Aquat. Sci., 10: 215-220.

Bailey, N. T. (1981). Statistical Methods in Biology. $2^{\text {nd }}$ ed. Biological Science Texts.

Brown, M.T.;Hodgkinson, W.M. and Hurd, C.L. (1999). Spatial and temporal variations in the copper and zinc concentrations of two green seaweeds from Otago Harbour, New Zealand. Marine Environ. Rese., 47: 175-184.

Caliceti, M.; Argese, E.; Sfriso, A. and Pavonim, B. (2002). Heavy metal contamination in the seaweeds of the Venice lagoon. Chem., 47: 443-454.

Chaudhuri, A.; Mitra, M.; Havrilla, C.; Waguespack, Y. and Schwarz, J. (2007). Heavy metal biomonitoring by seaweeds on the Delmarva Peninsula, east coast of the USA. Botanica Marina, 50: 151-158.

Dadolahi, A.; Nikvarz, A.; Mohamad, S.; Nabavi, B.; Safahyeh, A. and Ketal, M. (2011). Environmental monitoring of heavy metals in seaweed and associated sediment from the Strait of Hormuz, I.R. Iran. World J. Fish \& Marine Sci., 3 (6): 576-589.

El-Gohary, S. E.; Zaki, H. R. and El-Naggar, M. F. (2012). Geochemical study and distribution of some trace metals along the coastal zone of Abu-Qir bay, Mediterranean Sea-Alexandria, Egypt. World Appl. Sci. J., 18(8): 1011-1022.

El-Moselhy, K.M. and Gabal, M.N. (2004). Trace metals in water, sediments and marine organisims from the northern part of the Gulf of Suez, Red Sea. J. Marine Syst., 46: 39-46.

El-Nady, F.E. (1996). Heavy metal pollution problems in the southeastern Mediterranean waters of Alexandria, Egypt. Proceeding of the 6 international Conference on Environmental Protection is a Must. NIFO, VEA, ISA and SFD, Alexandria, Egypt, 21-32 May 1996, pp: 364-381.

EPA. (1992). Method 3005A. Test Methods for Evaluating Solid Waste. Laboratory manual physical/chemical methods. Office of Solid Waste and Emergency Response, Washington, DC.

Faragallah, H. M.; Askar, A. I.; Okbah, M. A. and Moustafa, H. M. (2009). Physicochemical characteristics of the open Mediterranean sea water far about $60 \mathrm{Km}$ from Damietta harbor, Egypt. J. Ecolo. Nat. Environ., 1 (5): 106-119.

Favero, N.; Cattalini, F.; Bertaggia, D. and Albergoni, V. (1996). Metal accumulation in a biological indicator (Ulva rigida) from lagoon of Venice (Italy). Archives of Environmental Contamination and Toxicology 31: 9-18.

Forsberg, A., Soderlund Frank, S.; Peterson, L. and Pedersen, M. (1988). Studies on metal content in the brown seaweed, Fucus vesiculosus, from the Archipelago of Stockholm. Environ. Pollution, 49: 245-263.

Foster, W. (1976). Concentration and concentration factors of heavy metals in brown algae. Environ. Pollution, 10: 45-53.

Giusti, L., (2001). Heavy metal contamination of brown seaweed and sediments from the U.K. coastline between the Wear River and Tees River. Environment International, 26: 275-286.

Gobas, F. A. and Morrison, H. A. (2000). "Biococentration and biomagnification in the aquatic environment". In Boethling RS, Mackay D, eds. Handbook of 
Property Estimation Methods for Chemicals: Environmental and Health Sciences. Boca Raton, FL, USA: Lewis. Pp. 189-231.

Haritonidis S. and Malea, P. (1999). Bioaccumulation of metals by the green alga Ulva rigida from Thermaikos Gulf, Greece. Envirom. Pollut., 104: 365-372.

Jothinayagi, N. and Anbazhagan C. (2009). Heavy Metal Monitoring of Rameswaram Coast by Some Sargassum species. American-Eurasian J. Sci. Res., 4 (2):73-80.

Kamala-Kannan S., Batvari B.P.D., Lee K.J., Kannan N., Krishnamoorthy R., Shanthi K., Jayaprakash M. (2007). Assessment of heavy metals (Cd, $\mathrm{Cr}$ and $\mathrm{Pb}$ ) in seaweed (Ulva lactuca) in the Publicat Lake, South East India. Chemosphere, 71: $1233-1240$.

Lozano, G.; Hardisson, A.; Gutierez, A. J. and Lafuente, M. A. (2003). Lead and cadmium levels in coastal benthic algae (seaweeds) of Tenerife, Canary Islands. Environ. Interna., 28 (7): 627-631.

Misheer, N.; Kindness, A. and Jonnalagadda, S. (2006). Seaweeds along KwaZuluNatal Coast of South Africa -3: Elemental Uptake by Ulva lactuca (Sea Lettuce) J. Environ. Sci. Health Part A., 41: 1249-1259.

Moore, J.W. and Ramamoorthy, S. (1984). Heavy metals in natural waters, applied monitoring and impact assessment. New York: Springer-Verlag. ISBN 0-38790885-4.

Munda, I.M. and Hudnik, V. (1986). Growth response of Fucus vesiculosus to heavy metals, singly and in dual combinations, as related to accumulation. Botanica Marina, 29: 401-412.

Okuku, E.O. and Peter, H.K. (2012). Choose of Heavy Metals Pollution Biomonitors: A Critic of the Method that uses Sediments total Metals Concentration as the Benchmark Int. J. Environ. Res., 6 (1):313-322.

Pérez, A. Á.; Farías, S. S.; Strobl, A. M.; Camarda, S.; Pérez, L. B.; Roses, O. and Fajardo, M. A. (2012). Studies on the nutritional contribution and seasonal variation of essentials minerals in edible seaweeds, Porphyra columbina and Ulva sp., from central Patagonia, Argentina. International J. Agricul. Sci., 2 (6): 186-197.

Perez-Lopez, M.; Alonso, J.; Novoa-Valinas, M. C. and Melgar, M. J. (2003). Assessment of Heavy Metal Contamination of Seawater and Marine Limpet, Patella 67ulgate L., from Northwest Spain. J. Environm. Sci. and Health, A38 (12): 2845-2856.

Rybak, A.; Messyasz, B. and Teska, B. (2012). Freshwater Ulva (Chlorophyta) as a bioaccumulator of selected heavy metals $(\mathrm{Cd}, \mathrm{Ni}$ and $\mathrm{Pb})$ and alkaline earth metals (Ca and $\mathrm{Mg}$ ). Chemosphere, 89: 1066-1076.

Rybak, A.; B. Messyasz and B. Leska. (2013). The accumulation of metal (Co, Cr, $\mathrm{Cu}, \mathrm{Mn}$ and $\mathrm{Zn}$ ) in freshwater Ulva (Chlorophyta) and its habitat. Ecotoxicol., 22:558-573.

Sawidis, S.; Brown, M.T.; Zachariadis, G. and Sratis, I. (2001). Trace metals concentrations in marine macroalgae from different biotopes in the Aegean Sea. Environ. Interna., 27: 43-47.

Shanmugam, A.; Sudharsan, S.; Seedevi, P.; Ramasamy, P.; Subhapradha, N. and Vairamani, S. (2012). Heavy metal accumulation in seaweeds and sea grasses along southeast coast of India. J. Chem. Pharm. Res., 4 (9):4240-4244.

Topcuoğlu, S.; Kılıç, Ö.; Belivermiş, M.; Ergül, H. and Kalayc, G. (2010). Use of marine algae as biological indicator of heavy metal pollution in Turkish marine environment. J.Black Sea/Mediterranean Environment, 16(1):43-52. 
Villares, R.; Puente, X. and Carballeira, A. (2001). Ulva and Enteromorpha as Indicators of Heavy Metal Pollution. Hydrobiologia, 462: 221-232.

Villares, R.; Puente, X. and Carballeira, A. (2002). Seasonal variation and background levels of heavy metals in two green seaweeds. Environmental Pollution, 119 (1): 79-90.

World Health Organization WHO. (2011). Iron, Zinc, Copper, Manganese, Cadmium and Lead in drinking-water. Guidelines for drinking-water quality, Geneva, World Health Organization. $4^{\text {th }}$ ed.

Zbikowski, R.; Szefer, P. and Latala, A. (2006). Distribution and relationships between selected chemical elements in green alga Enteromorpha sp. From the southern Baltic. Environmental Pollution, 143 (3): 435-448.

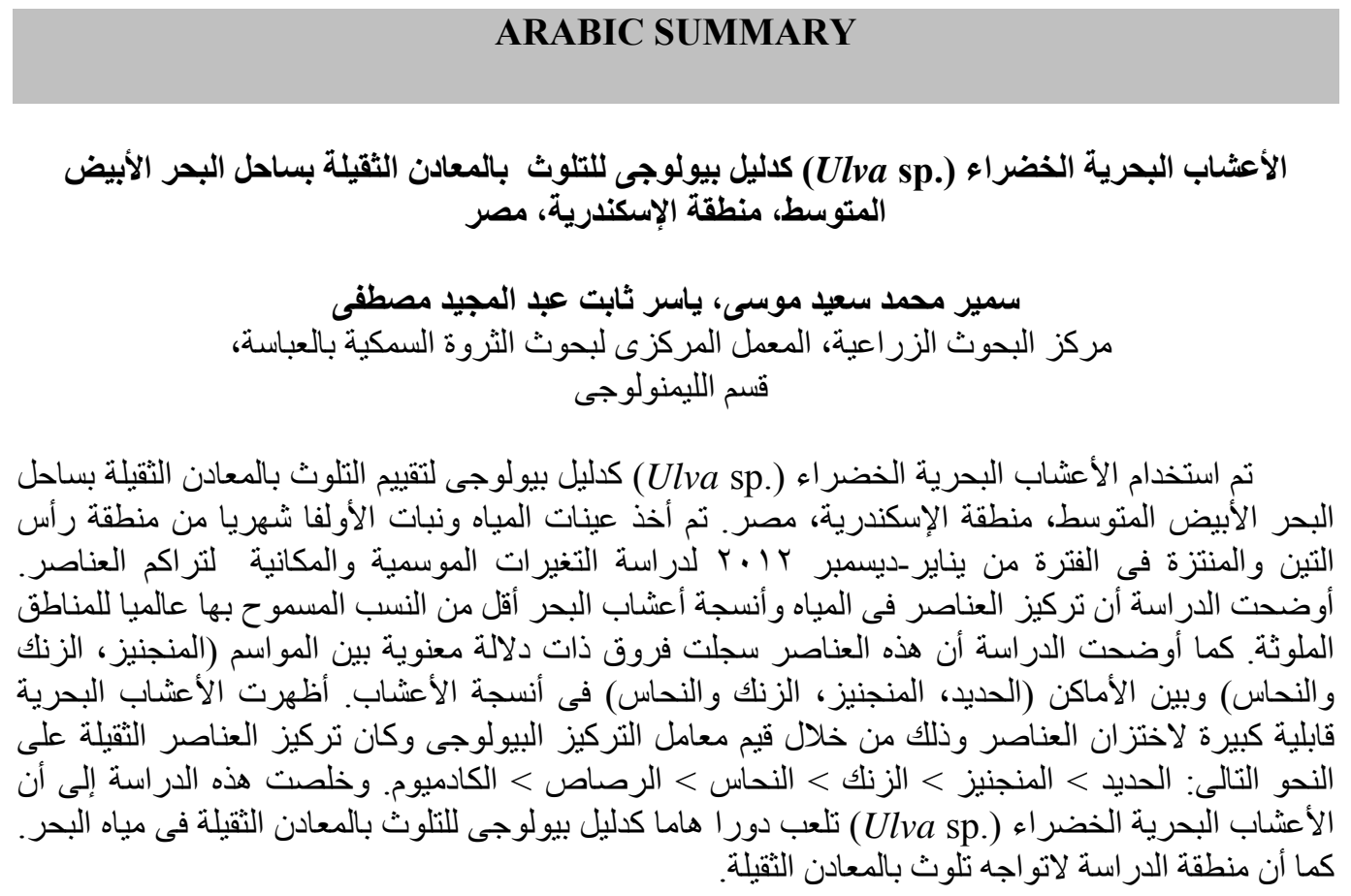

